\title{
The Bristol bulk handling terminal
}

\section{A. C. Burdall and L. H. Muir}

\section{P. E. Rans, MA, CEng, MICE, Technical Director, The Bristol Port Company}

I represented First Corporate Shipping, the owner of the Port of Bristol, throughout the project and I was subsequently appointed Managing Director of The Bristol Bulk Company Ltd, the company jointly owned by First Corporate Shipping and National Power which was established to manage the Terminal. I would like to congratulate Burdall and Muir on their paper and to add a few comments with respect to project organisation and the overall timescales.

The Port of Bristol was owned and managed by Bristol City Council (BCC) for nearly 150 years prior to 1991 . However, due to a combination of circumstances, BCC was prepared to sell the Port, which had become a liability due to the debt burden and significant losses on the petl account. Following an unsolicited approach from a private company, First Corporate Shipping, in 1990, began detailed negotiations which continued until the sale was concluded in August 1991. In parallel with these negotiations, First Corporate pursued contacts with potential new customers and their first meeting with National Power took place in March 1991. National Power itself had recently been privatised and proved itself capable of taking very rapid entrepreneurial action, in a way not characteristic of my own recollection of the old CEGB. Within a few weeks the project took on a life of its own. First Corporate commissioned a Conceptual Feasibility Study from Rendel Palmer and Tritton, the original designers of Royal Portbury Dock, and this was issued in early July 1991. The configuration of the terminal as built closely follows the layout proposed in this report.

One of the first decisions agreed between First Corporate and National Power was that the ship unloaders would be bucket wheel continuous ship unloaders, similar to three machines operated by National Power at power stations on the Thames. This decision was based on National Power's favourable experience of these machines and on First Corporate's concern that discharging of coal ships should be as environmentally friendly as possible in view of the other traffic in the port. Delivery of these machines was acknowledged to be on the critical path of the project. Negotiations with the Finnish manufacturer Kone Oy, now Konecranes VLC, started in June and specifications and commercial terms for the supply of two 2000 tph machines were agreed in July. However, at this point, the sale of the Port to First Corporate had not yet been completed and so it was not possible to place a full contract with Kone. Instead, National Power placed a small contract for pre-production design work, which enabled the critical path to be progressed.

By this time, the structure of the joint venture between National Power and First Corporate Shipping had been agreed. National Power would provide the bulk of the equipment, whereas First Corporate would provide the marine infrastructure, the land for development and the cargo handling expertise and would have use of the equipment for handling bulk materials, in particular animal feedstuff, for other customers. National Power therefore appointed Halcrow-Soros and, as described in the paper, formed the Joint Project Team and brought the project to its very rapid and successful completion. The role of the joint venture partners in facilitating rapid decision making should not be underestimated. It is difficult to believe that the project could have been started so quickly had not both these companies been privatised. Nor could the project have been completed as quickly had National Power not embraced the procurement procedures described in the paper. I wonder to what extent the experience of privatisation influenced National Power's procurement procedures.

From the point of view of First Corporate Shipping, which is now trading under the name of The Bristol Port Company, the completion of the project in December 1993 was not a significant date. Commercial operations effectively started in September 1993, when an animal feedstuff storage facility linked to the berths was commissioned. This facility was the result of a joint venture between The Bristol Port Company and United Molasses, a subsidiary of Tate and Lyle. The completion of the facility coincided with a period of low demand for imported coal and, as a direct result of low volumes of coal throughput, it took a long time to resolve the many problems which were outstanding following completion. These included, in particular, problems at the interfaces of the Main Contract and the major novated sub-contracts. The Joint Project Team has continued to be involved, although at a reduced level, and there remain a few issues that have not yet been resolved. The ship unloaders were effectively commissioned in commercial conditions while working on animal feed. Despite the expectation that coal volume would exceed animal feedstuff by a factor of 5:1, it was late in 1995 before the cumulative volume of coal handled overtook that of animal feed. 
Now, seven years after the first coal was handled, the Terminal is working with a high level of availability and is achieving the specified levels of performance. In total, over 12.5 million tonnes of various materials have been handled and throughput on an annualised basis which is currently close to the design levels. Undoubtedly, the Terminal reflects a great deal of credit on all those involved in its conception, design and construction. 